\title{
UPAYA GURU BIMBINGAN DAN KONSELING DALAM MENGATASI PERILAKU MALADAPTIF SISWA DENGAN LAYANAN KONSELING KELOMPOK
}

\author{
Satriya Tubagus ${ }^{1}$, Jarkawi², Farial $^{3}$ \\ ${ }^{1}$ Mahasiswa Prodi Bimbingan dan Konseling, FKIP, UNISKA MAB, Indoensia \\ ${ }^{2}$ Dosen Prodi Bimbingan dan Konseling, FKIP, UNISKA MAB, Indonesia \\ ${ }^{3}$ Dosen Prodi Bimbingan dan Konseling, FKIP, UNISKA MAB, Indoensia \\ Email : Satriya1415@gmail.com, jarkawi010462@gmail.com, madihah.alkareem@gmail.com
}

\section{ABSTRAK}

Penelitian ini bertujuan untuk mendeskripsikan 1). bentuk perilaku maladaptif siswa di SMPN 14 Banjarmasin, 2). faktor - faktor yang mempengaruhi perilaku maladaptif siswa di SMPN 14 Banjarmasin, 3).Upaya guru bimbingan dan konseling dalam mengatasi perilaku maladaptif siswa di SMPN 14 Banjarmasin. Metode yang di gunakan dalam penelitian ini adalah metode kualitatif dengan pendekatan deskriptif. Sumber data dalam penelitian ini adalah : Guru Bk, Guru Wali kelas, dan Siswa SMPN 14 Banjarmasin. Teknik pengumpulan data dalam penelitian ini menggunakan observasi, wawancara, dan dokumentasi. Adapun keabsahan data dalam penelitian ini menggunakan triangulasi dan perpanjangan keikutsertaan.Sedangkan analisis data yang di gunakan dalam penelitian ini adalah analisis membuat kesimpulan dari keseluruhan pembahasan.hasil dari penelitian ini menunjukan bahwa perilaku maldaptif siswa SMPN 14 Banjarmasin secara umum yang sering di lakukan yaitu membolos, membuat keributan di dalam kelas, dan membuly teman. Faktor penyebab terjadinya perilaku maladaptif siswa di SMPN 14 Banjarmasin adalah, Faktor kontrol diri yang lemah,faktor keluarga, dan faktor lingkungan atau teman sebaya yang tidak baik dan tidak mendukung dalam penyesuaian terhadap lingkungan. Upaya yang telah di lakukan Guru BK dalam mengatasi perilaku maladaptif siswa SMPN 14 Banjarmasin adalah mengidentifikasi masalah, mengumpulkan data siswa dan latar belakang siswa, melakukan kolaborasi dengan guru lain dan orang tua siswa dalam menyelesaikan masalah siswa di sekolah, memberi teguran atau hukuman serta nasihat yang sifatnya mengedukasi dan mendidik siswa itu sendiri.

Kata Kunci : Guru BK, Perilaku Maladaptif

\section{ABSTRACT}

This study aims to describe 1). forms of maladaptive behavior of students at SMPN 14 Banjarmasin, 2). factors - factors that affect students 'maladaptive behavior at SMPN 14 Banjarmasin, 3). Teacher guidance and counseling efforts in overcoming students' maladaptive behavior at SMPN 14 Banjarmasin. The method used in this study is a qualitative method with a descriptive approach. Data sources in this study are: Bk Teachers, Homeroom Teachers, and Students of SMPN 14 Banjarmasin. Data collection techniques in this study used observation, interviews, and documentation. The validity of the data in this study uses triangulation and extension of participation. While the analysis of the data used in this study is the analysis of making conclusions from the entire discussion. The results of this study indicate that the maldaptive behavior of SMPN 14 Banjarmasin students in general is often done that is ditching, making a fuss in the classroom, and bullying friends. Factors causing the maladaptive behavior of students at SMPN 14 Banjarmasin are, factors of weak self-control, family factors, and environmental factors or peers who are not good and do not support in adjusting to the environment. The efforts that have been done by BK Teachers in overcoming maladaptive behavior of SMPN 14 Banjarmasin students are identifying problems, collecting student data and student backgrounds, collaborating with other teachers and parents in solving students' problems at school, giving reprimands or punishment as well as advice its nature of educating and educating students themselves.

Keywords: Guidance and Counseling Teachers, Maladaptive Behavior 


\section{PENDAHULUAN}

Dalam proses belajar mengajar di sekolahan sering terjadi adanya masalah yang di alami siswa dalam proses penyesuaian diri di lingkungan sekitarnya. Oleh karena itu sering berdampak pada perilaku siswa yang tidak baik dalam penyesuaian dirinya. Kartika sari dewi (kesehatan mental, 2012: 28) mendeskripsikan bahwa "terdapat beberapa macam permasalahan perilaku manusia yang dapat di kontrol, merupakan perilaku defisit (rendah) dan perilaku berlebihan (excess ice behavior)". Dalam hal ini saya meneliti tentang perilaku seseorang yang sulit menyesuaikan diri di lingkungan sekolah. Perilaku berlebihan ini merupakan perilaku yang menimbulkan seseorang bersangkutan mengalami kesulitan beradaptasi di lingkungan sekitar. Sebagai gambaran merupakan tindakan yang dilakukan dengan merendahkan orang lain, mencela orang lain. Menurut Makmun, (2000:130) menjelaskan masa remaja adalah suatu masa melalui perkembangan yang di lewati individu remaja yang berjalan sejak selesainya masa kanak-kanak sampai munculnya dewasa awal. Perilaku maladaptif sering terjadi di kalangan remaja antara lain di sekolah SMP. Dalam periode tersebut seorang remaja baru memasuki periode peralihan dari anak-anak melangkah ke remaja awal sehingga dalam penyesuaian diri terhadap lingkungan masih labil dan belum adanya kematangan mengontrol diri sehingga seorang remaja dalam melakukan tindakan atau menyesuaikan diri dengan lingkungannya yang sifatnya ingin tahu dan mencoba untuk menemukan identitas dirinya sendiri. Maka sering terjadi munculnya perilaku maldaptif siswa di sekolah di sebabkan oleh faktor lingkungan yang tidak kondusif sehingga dapat berpengaruh terhadap perkembangan sosial nya. Menurut Syamsu. Y dan Junika N, landasan bimbingan dan konseling (2016:164), Mendeskripsikan bahwa dalam perilaku beradaptasi di lingkungan menyebabkan beberapa macam permasalahan khususnya bagi individu sendiri.
Banyak permasalahan yang terjadi terkait perilaku maladaptif remaja, perilaku tersebut juga menimpa dan terjadi di lembaga pendidikan. Seperti juga hal nya di salah satu lembaga pendidikan di SMPN 14 Banjarmasin. Berdasarkan salah satu sumber yang di temui peneliti, siswa siswinya juga mengalami masalah yang ujungujungnya mereka melakukan tindakan yang tidak melanggar peraturan atau disebut dengan perilaku maladaptif. Diantaranya seperti membolos dan bertengkar. terkait hal ini harus ada tindakan lanjut guna mengatasi masalah yang terkait dengan perilaku yng menyimpang yang di lakukan siswa - siswi tersebut sejak dini, oleh sebab itu jika tidak segera di beri tindakan maka di khawatirkan masalah nya akan lebih sulit di selesaikan karena sudah menjadi kebiasaaan. Terkait dengan permasalahan ini, Saya telah melakukan observasi dan wawancara di SMPN 14 Banjarmasin pada waktu melaksanakan ppl di sana ,berdasarkan informasi dari guru bimbingan dan konseling terkait dengan perilaku maladaptif yang dilakukan oleh siswa di SMPN 14 Banjarmasin. Beliau menjelaskan bahwa, masih banyak siswa yang melanggar peraturan, perilaku maladaptif yang di alami siswa di antaranya

1. Membuat keributan di dalam kelas

2. Membolos

3. Membully teman

Dalam penelitian ini Peneliti berfokus untuk meneliti tentang :

1. Perilaku - perilaku maladaptif siswa di SMPN 14 Banjarmasin .

2. Faktor - faktor yang mempengaruhi penyebab perilaku maladaptif siswa di SMPN 14 Banjarmasin.

3. Upaya guru bimbingan dan konseling dalam mengatasi perilaku maladaptif siswa di SMPN 14 Banjarmasin.

Berdasarkan latar belakang masalah yang terjadi saya peneliti merumuskan ada beberapa 
masalah yang dapat di rumuskan sebagai berikut :

1. Apa saja bentuk perilaku maladaptif siswa di SMPN 14 Banjarmasin?

2. Apa saja faktor-faktor penyebab perilaku maladaptif siswa di SMPN 14 Banjarmasin ?

3. Bagaimanakah upaya guru bimbingan dan konseling dalam mengatasi perilaku maladaptif siswa di SMPN 14 Banjarmasin ?

Tujuan penelitian ini adalah untuk mendeskripsikan:

1. Perilaku maladaptif siswa di SMPN 14 Banjarmasin.

2. Faktor-faktor penyebab perilaku maladaptif siswa di SMPN 14 Banjarmasin.

3. Upaya guru bimbingan dan konseling dalam mengatasi perilaku maladaptif siswa di SMPN 14 Banjaramsin .

\section{METODE}

Penelitian ini berdasarkan metode kualitatif dan desain penelitian menggunakan fenomenologi dan jenisnya menggambarkan. Penelitian deskriptif adalah penelitian yang bermaksud membuat perumpamaan, gambaran atau kerangka secara berurutan, faktual dan akurat mengenai hal yang terjadi, sifat - sifat serta berkaitan antar kejadian yang di teliti menurut Nazir, (2014:43). Berdasarkan penelitian yang digunakan adalah strategi kualitatif. Istilah penelitian kualitatif di jelaskan krik \& miller (dalam nasution,1988:23) pada dasarnya berasal dari pengamatan kualitatif dan di pertanyakan dengan pengamatan kuantitatif. Kehadiran peneliti tidak lain di maksudkan untuk mempengaruhi subjek penelitian, melainkan untuk memperoleh data dan informasi yang jelas dan tepat. Untuk mendapatkan data yang jelas dan tepat dapat digunakan beberapa metode, di antaranya dengan cara mengamati, berdialog, serta pengarsipan foto di lapangan.

Berdasarkan pelaksanaannya, peneliti berada di lapangan pada saat di perbolehkan melaksanakan penelitian, adapun caranya datang ke tempat penelitian pada jam tertentu dan tidak terjadwal secara berurutan. Adapun hal penting hadirnya peneliti di tempat penelitian ini bermaksud melaksanakan pencarian dan pengkajian data yang berkaitan dengan Upaya Guru Bimbingan Konseling dalam Menangani perilaku maladaptif siswa dengan layanan konseling kelompok di SMPN 14 banjarmasin. Guna memperoleh data yang lebih valid dan akurat seperti yang diharapkan dari peneliti, adapun data yang berkaitan langsung maupun tidak langsung berdasarkan masalah yang diangkat oleh peneliti sebagai judul skripsi. Adapun lokasi yang dilaksanakan oleh peneliti berlangsung sejak bulan April dengan bulan juli 2020. Adapun pelaksanaanya di SMPN 14 banjarmasin yang beralamat di Jalan banua anyar no. 14, rt.3, benua anyar, kec. Banjarmasin timur, kota Banjarmasin, kalimantan selatan 70121. Adapun sumber data Menurut zuldafrial (2012:46) merupakan subjek tempat asal data yang diperoleh. Oleh sebab itu peneliti mendeskripsikan ada beberapa nara sumber dalam pengumpulan data untuk keperluan penelitian ini yaitu:

1. Guru Bimbingan Konseling (BK)

2. Guru Wali Kelas

3. Murid SMPN 14 BANJARMASIN

Data utama dalam penelitian kualitatif bersumber dari kalimat obrolan dan tindakkan menggunakan cara mengambil sampel dari perwakilan murid yang ada di sekolah menengah pertama negeri 14 Banjarmasin pada kelas VIII yang berjumlah enam kelas adalah kelas VIII $A$, $B, C, D, E$, dan $F$. dari enam kelas peneliti mengambil sampel kelas VIII $A$, $E$ dan $F$ dengan alasan karena pada siswa kelas VIII A, E, dan F kebanyakan siswa yang melakukan pelanggaran sehingga peneliti memberikan gambaran dari permasalahan yang terjadi di sekolah dan upaya apa yang di persiapkan peneliti dalam mencari solusi permasalahanya. Adapun subjek dalam penelitiaan memiliki subjek yaitu guru BK di SMPN 14 banjarmasin yang berjumlah 1 orang 
dan siswa - siswi SMPN 14 Banjarmasin kelas VIII A, E, dan F .

Peneliti dalam penelitian kualitatif adalah instrument itu sendiri, keikutsertaan peneliti sangat menentukan dalam pengumpulan data. Keikut sertaan tersebut tidak hanya dilakukan dalam waktu singkat, tetapi memerlukan perpanjangan keikutsertaan pada latar penelitian. Adapun menurut Sugiyono (2015 : 244) mendeskripsikan bahwa ada beberapa teknik analisis data :

1. Reduksi Data (Data Reduction)

2. Penyajian Data (Display Data)

3. Verifikasi dan Menyimpulkan data (Conclusing drawing/ferivication)

Adapun analisis data yang digunakan dalam penelitian ini adalah analisis induktif. Artinya, analisis data induktif adalah berfikir yang berangkat dari fakta-fakta atau hal-hal yang bersifat khusus, kemudian ditarik suatu kesimpulan.

\section{HASIL DAN PEMBAHASAN}

Adapun hasil wawancara dan temuantemuan di lapangan, sesungguhnya terdapat beberapa permasalahan perilaku maladapif yang di alami seorang remaja di sekolah khususnya Siswa SMPN 14 banjarmasin.

1. Adapun bentuk - bentuk perilaku maladaptif siswa SMPN 14 Banjarmasin yaitu :

a. Membolos

Perbuatan membolos dapat dimaknai tidak datang ke sekolah tanpa alasan, tidak datang ke sekolah selama berhari-hari, dari rumah berpamitan pergi ke sekolah tetapi tidak datang ke sekolah menurut Gunarsa, singgih D, Psikologi Anak, Remaja Dan Keluarga,(2006:79)

b. Membuat keributan di dalam kelas

Bidell \& Deacon, (2010:3) mengatakan bahwa, Perilaku tidak menyenangkan di kelas atau Disruptive Classroom Behaviors (DCB) dapat di maknai sebagai perbuatan terlihat yang berlangsung didalam kelas yang membuat onar disaat guru mengajar atau mengganggu konsentrasi siswa yanglain.

c. Membuly teman

Perbuatan bullying merupakan hasrat untuk menyakiti. Hasrat ini diperlihatkan dalam tindakan, mengakibatkan orang lain menderita menurut Rigby (2005; dalam Anesty, 2009)

Berdasarkan teori dan temuan di lapangan dapat di maknai bahwa perilaku maladaptif siswa di sebabkan karena kemampuan seseorang yang sulit dalam menyesuaikan diri di lingkungan sekitar, yang di sebabkan oleh beberapa faktor sehingga menimbulkan dampak perilaku yang negatif . Adapun perilaku yang sering terjadi di sekolah SMPN 14 Banjarmasin perilaku membolos disebabkan oleh pembelajaran yang monoton sehingga siswa malas belajar, perilaku membuat keributan dalam kelas merupakan perilaku mengganggu teman di kelas di sebabkan oleh kurangnya perhatian dari guru maupun orang tua dan perilaku tindakan agresif atau bullying merupakan perilaku yang tidak menyenangkan terhadap orang lain dan berulang dengan tindakan menyebut sebutan nama jelek terhadap sesama teman atau korban bullying.

Sebagaimana di kemukakan Rigby (2005; dalam Anesty, 2009) Perbuatan bullying merupakan hasrat untuk menyakiti. Dan hasil penelitian tentang perilaku bullying menunjukan bahwa perilaku bullying di lapangan di sebabkan oleh rasa bangga pelaku ingin mendapatkan sebuah pujian dari teman lainnya agar di tertawakan oleh teman lain nya dengan cara memanggil korban dengan nama hinaan.

Begitu juga hasil penelitian tentang perilaku membolos menunjukan bahwa siswa membolos karena adanya suatu masalah keluarga dan kurang menariknya pelajaran yang di sampaikan guru di sekolah sehingga rasa semangat siswa untuk datang kesekolahan menjadi malas. Sebagaimana di kemukakan Gunarsa, singgih D, Psikologi Anak, Remaja Dan Keluarga, (2006:79) 
bahwa Perbuatan membolos dapat dimaknai tidak datang ke sekolah tanpa alasan, tidak datang ke sekolah selama berhari-hari, dari rumah berpamitan pergi ke sekolah tetapi tidak datang ke sekolah. Adapun hasil penelitian di lapangan tentang perilaku gaduh di dalam kelas perilaku tersebut di sebabkan oleh kurang perhatian guru terhadap siswa nya sehingga siswa melakukan hal-hal yang membuat siswa agar selalu di perhatikan oelh guru dan temantemannya. Sebagaimana di kemukakan Bidell \& Deacon, (2010:3) mengatakan bahwa, Perilaku tidak menyenangkan di kelas atau Disruptive Classroom Behaviors (DCB) dapat di maknai sebagai perbuatan terlihat yang berlangsung didalam kelas yang membuat onar disaat guru mengajaratau mengganggu konsentrasi siswa yang lain.

2. Berdasarkan hasil temuan di lapangan adapun faktor - faktor yang mempengaruhi perilaku maladaptif siswa tersebut antara lain :

a. faktor keluarga.

Kartini Kartono, Kenakalan Remaja. (2013:57) menjelaskan bahwa : Kenakalan yang di perbuat oleh anakanak dan khususnya remaja pada umumnya adalah hasil dari transisi perilaku mental orang tua, anggota keluarga, dan kondisi sekitar tetangga dekat, ditambah dengan nafsu primitif dan agresivitas yang tidak terkontrol semua itu berpengaruh kepada mental dan kehidupan perasaan remaja yang belum matang dan sangat labil.

b. faktor lingkungan masyarakat.

Lingkungan sosial dimana siswa berinteraksi langsung di masyarakat dengan budaya yang kurang baik akan berpengaruh pada proses kemampuan penyesuaian diri anak atau siswa dalam mengembangakan kemampuanya sehingga mengalami kesulitan dalam proses penyesuaian dengan lingkungan yang baik. c. faktor lingkungan pendidikan / sekolah. Lingkungan pendidikan merupakan lingkungan berkumpulnya seluruh siswa yang mempunyai pribadi yang baik maupun yang buruk untuk melaksanakan proses pembelajaran. siswa yang salah memilih teman akan berakibat kepada proses penyesuaian diri siswa terhadap peraturan yang di tetapkan di sekolah sehingga dapat memperhambat proses sosialisasi siswa di sekolah menjadi kurang baik.

Berdasarkan teori dan hasil temuan dapat di maknai bahwa penyebab perilaku maladaptif siswa di sebabkan oleh beberapa faktor yang mempengaruhi kemampuan penyesuaian diri siswa terhadap lingkungan adalah: faktor dalam diri, faktor keluarga, lingkungan masyarakat dan sekolah.

Sebagaimana di kemukakan Simanjuntak, latar belakang Kenakalan Remaja, (1983:121) bahwa Seperti di ketahui ada tiga lingkungan yang mempengaruhi perkembangan anak atau remaja yaitu lingkungan keluarga, sekolah dan masyarakat. Dan hasil penelitian tentang penyebab perilaku maladaftif di sekolahan di sebabkan oleh faktor lingkungan keluarga, faktor teman atau masyarakat dan faktor lingkungan sekolah.

Begitu juga hasil-hasil penelitian tentang kenakalan yang di lakukan oleh anakanak khususnya anak remaja pada umumnya adalah hasil dari perpindahan perilaku mental orang tua, anggota keluarga, dan kondisi sekitar tetangga dekat, ditambah dengan keinginan primitif dan agresivitas yang tidak terkontrol (Kartini Kartono, Kenakalan Remaja, 2013:57).

Hasil penelitian tentang faktor perilaku maladaptif menunjukan bahwa sikap dan perilaku anak tergantung apa yang dia tiru di saat berinteraksi dengan lingkungan sekitar. 
3. Berikut uraian pembahasan berdasarkan hasil wawancara terhadap beberapa informan tentang Upaya Guru BK dalam mengatasi perilaku maladaptif siswa adalah:

a. Identifikasi masalah

Guru BK memanfaatkan kemampuan dan wawasan yang lebih banyak dari siswa untuk memberikan informasi atau mencari solusi berkaitan dengan masalah yang belum diketahui oleh siswa. Sebagaimana di kemukakan Sarlito, Psikologi Remaja, (2011:228) dengan cara memberitahu tentang akibat dari perilaku yang menyimpang.

Dan hasil penelitian tentang identifikasi masalah adalah usaha guru bk mengamati dan mencari tahu data siswa hal apa yang menyebabkan terjadi nya masalah yang di alami siswa (Sarlito, Psikologi Remaja, 2011:228).

b. Pemberian bimbingan peringatan dan hukuman

Bimbingan yaitu upaya pertolongan terhadap seseorang yang memerlukan. pertolongan tersebut di berikan secara bermaksud, terukur dan sistematis, terbuka atas kesadaran klien atau murid tersebut, terkait dengan masalahnya. Sedangkan hukuman merupakan usaha untuk melakukan sesuatu yang memberikan efek jera kepada siswa yang telah melanggar peraturan di sekolah. Sebagaimana di kemukakan "bila dipandang perlu tindakan hukuman kepada remaja atau siswa yang melanggar tata tertib bisa dijalankan berupa sanksi hukuman (Aat Syafaat, Peranan Pendidikan, 2008:144).

Dalam hal ini guru BK memberikan bimbingan peringatan atau pencegahan serta hukuman untuk siswa yang sudah terlanjur melanggar peraturan di sekolah agar siswa tidak mengulangi perbuatanya. Dan hasil penelitian menunjukan bahwa dengan bentuk pemberian hukuman siswa akan jera dan tidak mengulanginya lagi (Aat Syafaat, Peranan Pendidikan, 2008:144).

c. Kerjasama para guru

Untuk mencapai hasil yang maksimal dalam sebuah usaha tentu kita membutuhkan orang yang bisa membantu kita dalam menggapai target yang diinginkan atau disebut dengan kerjasama. Sebagaimana yang dikatakan oleh Syamsu Yusuf, "kerjasama yaitu sikap mau bekerjasama dengan kelompok" (syamsu yusuf, Psikologi perkembangan anak, 2011:125). Dalam hal ini guru BK bekerja sama terhadap wali kelas atau orang tua untuk menyelesaikan masalah yang di alami siswa di sekolahan. Dan hasil penelitian sangat efektif dalam membantu menyelesaikan masalah siswa dalam pengumpulan data siswa sehingga tercapailah keinginan bersama (syamsu yusuf, Psikologi perkembangan anak, 2011:125).

Berdasarkan hasil temuan dalam pembahasan peneliti mendeskripsikan bahwa upaya yang di lakukan guru BK dalam mengatasi perilaku maladaptif siswa di SMPN 14 Banjarmasin dengan cara :

1. Identifikasi masalah siswa.

Merupakan usaha mencari jalan keluar masalah yang di alami siswa. Sebagaimana di kemukakan oleh (Sarlito, Psikologi Remaja. 2011:228). Dan hasil penelitian menunjukan bahwa identifikasi masalah merupakan langkah awal yang di ambil guru bk dalam mengatasi perilaku maladaptif siswa di sekolah (Sarlito, Psikologi Remaja. 2011:228).

2. Memberikan sebuah teguran dan hukuman.

Merupakan usaha pemberian peringatan agar siswa jera dan tidak mengulangi perbuatanya. Begitu juga 
hasil hasil penelitian bahwa dengan memberikan hukuman siswa akan membuat cara guru bk lebih efektif dan memberikan rasa jera dan takut untuk mengulangi perbuatanya lagi (Aat Syafaat, Peranan Pendidikan, 2008:144).

3. Kerjasama antar guru di sekolah dan orang tua.

Merupakan usaha guru bk dengan guru lain yang berada di sekolah serta orang tua siswa untuk membantu mencari jalan terbaik untuk penyelesaian masalah yang dialami siswa.Dan hasil penelitian menunjukan bahwa dengan adanya kerja sama orang tua mampu membina suasana yang baik dan menimbulkan efek yang positif terhadap perilaku anak di sekolah (syamsu yusuf, Psikologi perkembangan anak, 2011:125).

Berdasarkan teori dan hasil temuan dapat di maknai bahwa upaya guru Bk dalam mengatasi perilaku Maladaptif siswa di SMPN 14 Banjarmasin dengan beberapa langkah yang telah di lakukan yaitu: mengidentifikasi masalah siswa, memberi bimbingan peringatan atau bimbingan kelompok sifat nya pencegahan, selanjutnya memberikan hukuman atau konseling kelompok yang sifatnya pengentasan masalah, dan kerja sama antar guru untuk memudahkan mencari data siswa yang bermasalah sehingga dalam penanganan masalah siswa dapat di optimalkan.

\section{SIMPULAN}

Berdasarkan pemaparan dari pembahasan di atas terdapat beberapa masalah perilaku maladaptif yang di alami seorang remaja di sekolah SMPN 14 Banjarmasin.

1. Adapun bentuk bentuk perilaku maladaptif siswa SMPN14 Banjarmasin berdasarkan hasil temuan :

a. Membolos
Siswa membolos karena proses pembelajaran sangat membosankan dan kurang menarik sehingga siswa malas untuk datang kesekolah.

b. Membuat keributan di dalam kelas

Siswa membuat keributan di dalam kelas karena siswa ingin mendapatkan perhatian lebih dari teman maupun guru nya.

c. membuly teman

Siswa menghina teman dengan perkataan yang tidak baik karena pelaku merasa bangga dan di perhatikan oleh teman sekelas nya bahwa perilaku nya tersebut membuat banyak teman nya yang tertawa terhadap perilakunya.

2. Adapun faktor faktor yang mempengaruhi perilaku maladaptif siswa berdasarkan hasil temuan :

a. faktor keluarga

faktor keluarga di jelaskan dengan siswa yang di besarkan di dalam keluarga yang orang tua nya bercerai dan orang tua yang sibuk bekerja.

b. faktor lingkungan masyarakat

di sini peneliti menjelaskan bahwa lingkungan yang tidak baik membuat siswa untuk mengikuti budaya yang ada di masyarakat sehingga menimbulkan perilaku maladaptif.

c. faktor lingkungan sekolah

Adapun faktor di sekolah dalam penelitian ini di jelaskan bahwa siswa itu salah memilih teman di sekolah dalam berinteraksi dan bersosialisasi di lingkungan sekolah sehingga menimbulkan perilaku yang bertentangan terhadap peraturan di sekolah.

3. Adapun upaya guru bk dalam mengatasi perilaku maladaptif siswa SMPN 14 Banjarmasin dengan cara :

a. identifikasi masalah siswa. 
b. melakukan pengumpulan data untuk melihat latar belakang siswa.

c. kerjasama antar guru dan osis di sekolah beserta orang tua untuk bahu membahu menyelesaikan masalah siswa yang ada di sekolah maupun di luar sekolah.

d. Memerikan bimbingan dan konseling dengan cara memberi teguran atau point serta hukuman yang sifatnya mendidik.

Berdasarkan hasil penelitian di SMPN 14 Banjarmasin, dalam hal ini peneliti menyampaikan saran-saran yaitu:

1. Untuk guru bimbingan konseling

Mengingat banyaknya masalah dialami siswa ,maka guru Bimbingan konseling di harapkan agar lebih sabar, cermat dan profesional dalam membantu, mengarahkan dan menangani masalah yang di hadapi siswa.

2. Untuk siswa

Seharusnya siswa harus mampu menyesuaikan diri dengan baik dan selalu mentaati peraturan sekolah dan pandai bergaul dalam memilih teman yang baik di lingkungan sekolah maupun masyarakat.

3. Untuk orang tua

Seharusnya para orang tua memberikan pendidikan akhlak, pengetahuan nilai- nilai agama dan norma kehidupan, bimbingan, pengawasan dan perhatian yang penuh terhadap perkembangan anak.

4. Untuk sekolah

Sekolahan juga harus berperan aktif dalam membantu menyelesaikan masalah dengan memberikan program bimbingan berdasakan proses belajar mengajar yang baik untuk murid agar murid dapat memahami perannya sebagai siswa di sekolah.

5. Untuk peneliti yang lain
Untuk hasil penelitian ini di harapkan dapat membantu peneliti lain dalam mengembangkan lebih dalam lagi terhadap program bimbingan dan konseling di sekolah terutama SMP.

\section{DAFTAR PUSTAKA}

Aat Syafaat. 2008 .Peranan Pendidikan Agama Islam Dalam Mengatasi Kenakalan Remaja. Jakarta: PT Raja Grafindo Persada. Zuldafrial (2012:46), Sugiyono (2015 : 244).

Gunarsa, S.D. 2009. Psikologi untuk keluarga. Jakarta : Gunung Mulia.

Gunarsa, S.D., \& Gunarsa, Y.S.D (2006). Psikologi Perkembangan Anak Dan Remaja. Jakarta :PT BPK Gunung Mulia.

H.Kamaludin : Bimbingan dan Konseling Sekolah. Jurnal Pendidikan dan Kebudayaan , Vol.17, No.4, Juli 2011.

Jarkawi : Strategi Intervensi Pengembangan Karakter Remaja Dalam Sistem Nilai Menuju Indonesia Emas. Jurnal Arrahman ISSN : 2477-6300 / Vol.2 No.1.

Kartini kartono. 2013. Patologi sosial 2 .kenakalan remaja. Jakarta: PT Raja Grafindo Persada

Oop sopiah : Bimbingan Dan Konseling Terhadap Karyawan Perempuan Dalam Meningkatkan Kesejahteraan Ekonomi Keluarga. Jurnal Bimbingan, Penyuluhan, Konseling, Dan Psikoterapi Islam, vol 5, no.4, 2017, 43-448.

Prayitno \& Erman Amti.2013.Dasar-Dasar Bimbingan Dan Konseling.Jakarta: PT RINEKA CIPTA.

Sarlito Wirawan Sarwono. 2011. Psikologi Remaja. Jakarta: PT.Raja Grafindo Persada.

Satori Djam'an \& Aan komariah. 2014. Metodelogi Penelitian Kualitatif. Bandung : CV ALVABETA. 
Satori Djam'an \& Aan komariah. 2014. Metodelogi Penelitian Kualitatif. Bandung : CV ALVABETA

Syamsu Yusuf. 2011. Psikologi Perkembangan Anak \& Remaja. Bandung:PT Remaja Rosdakarya.

Taufiq hendra wicaksono : Perilaku Mengganggu Di Kelas. Journal UNY, 2012.

Tohirin. 2011. bimbingan dan konseling di sekolah dan madrasah. Jakarta : Rajawali Pers.

Yusuf, Syamsu \& Nurisah, Junika .2012, Landasan Bimbingan Dan Konseling. Bandung: Remaja Rosadakarya 